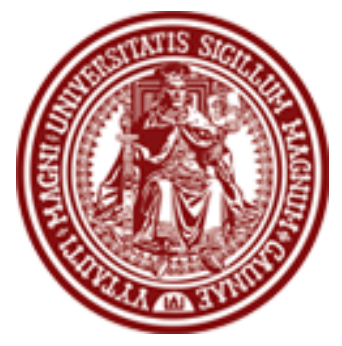

BALTIC JOURNAL OF LAW \& POLITICS

VOLUME 6, NUMBER 2 (2013)

ISSN 2029-0454

http://www.degruyter.com/view/j/bjlp

Cit.: Baltic Journal of Law \& Politics 6:2 (2013): 102-123

DOI: $10.2478 / \mathrm{bjlp}-2013-0013$

\title{
THE SUPREME COURT OF CANADA AND THE OFFENDER'S \\ RIGHT TO BE TRANSFERRED TO SERVE HIS SENTENCE IN \\ CANADA: INTERPRETING THE INTERNATIONAL TRANSFER OF \\ OFFENDERS ACT IN LIGHT OF CANADA'S NATIONAL AND \\ INTERNATIONAL HUMAN RIGHTS OBLIGATIONS
}

\author{
Jamil Ddamulira Mujuzi \\ Associate Professor; Research Fellow \\ University of the Western Cape Faculty of Law (Republic of South Africa) \\ Africa) \\ Contact information \\ Address: Private Bag X 17, Bellville 7535, Republic of South Africa \\ Phone: +27219593286/3299 \\ E-mail address: djmujuzi@gmail.com
}

University of the Western Cape Community Law Centre (Republic of South

Received: December 2, 2013; reviews: 2; accepted: December 30, 2013.

\section{ABSTRACT}

In September 2013 in the case of Divito $v$ Canada (Public Safety and Emergency Preparedness) the Supreme Court of Canada dealt with the issue of whether section 6(1) of the Canadian Charter of Rights and Freedoms, the Charter, which grants Canadians the right to enter Canada was violated in a case where the Minister of Public Safety and Emergency Preparedness declined to consent to the transfer of a Canadian citizen to serve his sentence in Canada where the sentencing state had consented to the transfer. Another issue was whether sections $8(1)$ and $10(1)(a)$ and $10(2)(a)$ of the International Transfer of Offenders Act, which granted the Minister the discretion to consent or not to consent to the transfer, were contrary to section 6(1) of the Charter. In resolving the above issues, the Court referred to its earlier jurisprudence, academic publications and international law. Although the Court agreed with the government that the appeal was moot because the appellant had 
left the USA by the time it was heard, it held that it retained "a residual discretion to decide the merits of a moot appeal if the issues raised are of public importance" and that this case was one of public importance because "[t]he issues are likely to recur in the future and there is some uncertainty resulting from conflicting decisions in the Federal Court." The purpose of this article is to highlight the interpretative tools invoked by the court and the implications of the judgement.

\section{KEYWORDS}

Supreme Court, Canada, transfer, offender, rights, rehabilitation

\section{NOTE}

The author presented some of the issues in this article at the $31^{\text {st }}$ Annual Conference of the Association of Third World Studies, "Prioritizing the Future: Continuity and Change in the Global South in the 21st Century", Indian Institute of Technology Madras, Chennai, India December 28-30, 2013. The author is grateful to the University of the Western Cape and to the South African National Research Foundation (NRF) for funding his conference attendance. This work is based on the research supported partly by the National Research Foundation of South Africa (Grant specific unique reference number (UID) 86004). The author acknowledges that opinions, findings and conclusions or recommendations expressed in this paper are those of the author and that the NRF accepts no liability whatsoever in this regard. 


\section{INTRODUCTION}

There are hundreds of Canadians serving prison sentences in other countries, most of them in the United States of America. There are also many foreign nationals serving prison sentences in Canada. ${ }^{1}$ In order to ensure that Canadians who are imprisoned abroad are transferred to serve their sentences in Canada, Canada has taken three approaches: it has ratified multilateral treaties on the transfer of offenders; it has signed bilateral treaties on the transfer of offenders with different countries; and it has enacted domestic legislation, the International Transfer of Offenders Act, to give effect to those international treaties. ${ }^{2}$ For an offender to be transferred to serve his sentence in Canada, the consent of the offender, that of the sentencing state and that of Canada is required. None of the multilateral or the bilateral agreements provide for the offender's right to be transferred to serve his sentence in Canada. ${ }^{3}$ The ITOA is also silent on that issue. However, Article 6(1) of the Canadian Charter of Rights and Freedoms provides that every citizen of Canada has a right to enter, remain in and leave Canada. At the same time, the International Transfer of Offenders Act gives the minister the discretion to refuse or allow a request by a Canadian imprisoned abroad to serve his sentence in Canada even if the sentencing state has consented to the transfer of the offender. The question is whether the relevant provisions of the International Transfer of Offenders Act are contrary to section 6(1) of the Charter in the sense that they violate the offender's right to enter Canada. This is the issue that the Supreme Court dealt with in the September 2013 case of Divito $v$ Canada (Public Safety and Emergency Preparedness) ${ }^{4}$ and will be the focus of this article. The fact that the Supreme Court's decision in this case is of significant policy importance is recognised by the Court itself. By the time the case was heard by the Court the applicant had already returned to Canada after serving his sentence in the USA and the government argued that the case was moot. ${ }^{5}$ The Court agreed with the government that the case was indeed moot but held that it "retains a residual discretion to decide the merits of a moot appeal if the issues raised are of public importance ... [and that] this is such a case. The issues are likely to recur in the future and there is some uncertainty resulting from conflicting decisions in the

\footnotetext{
1 Jamil D. Mujuzi, "The Transfer of Offenders from Other Countries to Canada: Analysing the Theory and Practice," The Chinese Journal of Comparative Law (2013): 2 // doi:10.1093/cjcl/cxt019.

2 Ibid.: 2.

${ }^{3}$ Ibid.: $12-16$.

${ }^{4}$ Divito v. Canada (Public Safety and Emergency Preparedness), 2013 SCC 47 (September 19, 2013).

${ }^{5}$ Ibid., para 50.
} 
Federal Court." ${ }^{\prime 6}$ In this article, the author intends to achieve the following objectives: highlight the different interpretative tools invoked by the Court to resolve the issues in question; and argue that the majority erred in their interpretation of the relevant provisions of the ITOA. The author also discusses the implications that the decision is likely to have on the interpretation of some of the factors in the International Transfer of Offenders Act - those that have to do with human rights - that the minister is empowered to take into consideration in deciding whether or not to consent to the transfer of the offender to serve his sentence in Canada. Before I deal with that case, I will first outline the conditions that have to be met before an offender is transferred to serve his sentence in Canada.

\section{CONDITIONS THAT HAVE TO BE MET FOR AN OFFENDER TO BE TRANSFERRED TO SERVE HIS SENTENCE IN CANADA}

The conditions that have to be met before an offender is transferred to serve his sentence in Canada are found in the multilateral treaties that Canada has ratified, ${ }^{7}$ the bilateral treaties it has signed with other countries, ${ }^{8}$ and in the ITOA. These conditions are: ${ }^{9}$ the conduct for which the offender was sentenced is one which is punishable as a crime in the sentencing state and in Canada; ${ }^{10}$ the offender is a citizen of Canada; ${ }^{11}$ the person has not been convicted of a strictly military offence; ${ }^{12}$ at least six months of the sentence remain to be served at the

\footnotetext{
${ }^{6}$ Ibid., para 51 ; see also para 55.

7 For the conditions of transfer in multilateral treaties, see United Nations Office on Drugs and Crime, Handbook on the International Transfer of Sentenced Persons (New York, 2012), p. $25-42$.

${ }^{8}$ For the official citations of these treaties see Jamil D. Mujuzi, supra note 1:2-3.

${ }^{9}$ It should be noted that some conditions are included in some agreements and not in others.

10 Agreement with Argentina (Article III(a)); Agreement with Barbados (Article IV(A)) (the word elements of the offence are used); Agreement with Bolivia (Article III(1)); Agreement with Brazil (Article $\operatorname{III}(a))$; Agreement with Cuba (Article III(a)); Agreement with the Dominican Republic (Article III(a)); Agreement with Egypt (Article 3(1)(e)); Agreement with Mexico (Article II(a)); Agreement with Mongolia (Article III(a)); Agreement with Morocco (Article 3(1)(E)); Agreement with Peru (Article III(1)); Agreement with Thailand (Article II(1)); and Agreement with the United States of America (Article II(a)). ${ }_{11}$ Agreement with Argentine (Article III(b)); Agreement with Barbados (Article IV(B)); Agreement with Bolivia (Article III(2)); Agreement with Brazil (Article III(b)); Agreement with Cuba (Article III(b)); Agreement with the Dominican Republic (Article III(b)); Agreement with Egypt (Article 3(1)(a)); Agreement with France (Article II(c)) (the word national is used); Agreement with Mexico (Article II(b)) (the word national is used); Agreement with Mongolia (Article III(b)); Agreement with Morocco (Article $3(1)(A)$ ) (the word national is used); Agreement with Peru (Article III(2)); Agreement with Thailand (Article II(2)) (the word national is used); and Agreement with the United States of America (Article II(b)). In Catenacci v. Canada (Attorney General), 2006 CarswellNat 1364, 2006 FC 539, 144 C.R.R. (2d) 128, 291 F.T.R. 215 the Canadian Federal Court held that an a permanent resident does not qualify to be transferred to serve his sentence in Canada. Plachta has argued that "the domicile (residence) test [instead of the citizenship or nationality criterion] offers a better and more flexible solution" (see Michael Plachta, "Human Rights Aspects of the Prisoner Transfer in a Comparative Perspective," 53 (1993) Louisiana Law Review: 1047).

${ }_{12}$ Agreement with Argentine (Article III(c)); Agreement with Barbados (Article IV(C)); Agreement with Bolivia (Article III(4)); Agreement with Cuba (Article III(c)); Agreement with the Dominican Republic (Article III(c)); Agreement with France (Article III(b)); Agreement with Mongolia (Article III(c)); Agreement with Peru (Article III(4)); Agreement with Thailand (Article II(3)) (the Agreement with Thailand provides for other grounds in the following terms: That the offender to be transferred was not
} 
time of the application ${ }^{13}$-although in some circumstances the transfer can take place where the period left to be served is less than six months; or at the time of receipt of the request for transfer the sentenced person still has at least one year of the sentence to serve ${ }^{; 14}$ the sentence is final, in other words, that no proceeding by way of appeal or by extraordinary review procedure of the conviction or sentence is pending in the sentencing state and that the prescribed time for appeal has expired; ${ }^{15}$ the offender has consented to the transfer; ${ }^{16}$ that the sentencing state and Canada have agreed or consented to the transfer; ${ }^{17}$ that the offender has not been sentence to death unless if he was sentenced to death the death penalty was commuted; ${ }^{18}$ that the provisions of the sentence, other than the period of detention or any period of probation, have been complied with; ${ }^{19}$ that the offender is not a domiciliary of the sentencing state; ${ }^{20}$ that the offender has served the minimum period required to be served by the law of the sentencing state. ${ }^{21}$ In deciding whether or not to consent to the transfer of a Canadian national or citizen to serve

being punished in Thailand for an offence: (a)against the internal or external security of the State;(b)against the Head of State of the Transferring State or a member of his family; or(c)against legislation protecting national art treasures.); Agreement with the United States of America (Article $\mathrm{II}(\mathrm{c})$ ) (the treaty also provides that the offence should not be one against immigration laws).

${ }_{13}$ Agreement with Argentine (Article III(d)); Agreement with Barbados (Article IV(D)); Agreement with Bolivia (Article III(5)); Agreement with Brazil (Article III(c)); Agreement with Cuba (Article III(d)); Agreement with the Dominican Republic (Article III(d)); Agreement with Egypt (Article 3(1)(c)) (or the sentence is indeterminate); Agreement with Mexico (Article II(d)); Agreement with Mongolia (Article III(d)); Agreement with Peru (Article III(5)); and Agreement with the United States of America (Article $\operatorname{II}(d))$.

${ }_{14}$ Agreement with Morocco (Article 3(1)(C)) (article 3(2) of the Agreement with Morocco provides that "In exceptional cases, the Parties may agree to a transfer even if the time to be served by the sentenced person is less than that specified in paragraph $1 \mathrm{C}$ of this Article"); Agreement with Thailand (Article $\mathrm{II}(4))$.

${ }_{15}$ Agreement with Argentine (Article III(e)); Agreement with Barbados (Article IV(F)); Agreement with Bolivia (Article III(6)); Agreement with Brazil (Article III(d)); Agreement with Cuba (Article III(e)); Agreement with the Dominican Republic (Article III(e)); Agreement with Egypt (Article 3(1)(b)) (it also provides that the offender may waive his right of appeal); Agreement with France (Article II(b)); Agreement with Mexico (Article II(e)); Agreement with Mongolia (Article III(e)); Agreement with Morocco (Article $3(1)(B)$ ) (this agreement provides that the judgment has to be enforceable); Agreement with Peru (Article III(6)); Agreement with Thailand (Article II(5)) and Agreement with the United States of America (Article II(e)).

16 Agreement with Argentine (Article III(f)); Agreement with Barbados (Articles VII(2) and VIII); Agreement with Bolivia (Article V(4) and (9)); Agreement with Brazil (Article V(6)); Agreement with Cuba (Article III(f)); Agreement with the Dominican Republic (Article III(f)); Agreement with Egypt (Article 3(1)(d)); Agreement with France (Article II(d)); Agreement with Mexico (Article IV(3)); Agreement with Mongolia (Article III(f)); Agreement with Morocco (Article 3(1)(D)); Agreement with Thailand (Article III(7)); and Agreement with the United States of America (Article III(10)).

17 Agreement with Argentine (Article III $(g)$ ); Agreement with Cuba (Article III $(g)$ ); Agreement with the Dominican Republic (Article III(g)); Agreement with Egypt (Article 3(1)(f)); Agreement with Mexico (Article IV); Agreement with Mongolia (Article III(g)); Agreement with Morocco (Article 3(1)(F)); Agreement with Thailand (Article VII(I)). It should be noted that the agreement with France is silent on the consent of both the sentencing and the administering state before the transfer takes place. In practice however, the transfer is only likely to take place with the consent of both countries.

18 Agreement with Barbados (Article IV(E)); Agreement with Bolivia (Article III(3)); Agreement with Cuba (Article III(h)); Agreement with Peru (Article III(3)).

${ }_{19}$ Agreement with Bolivia (Article III(7)); Agreement with Peru (Article III(7)).

20 Agreement with Mexico (Article II(c)). The case of transfers to or from Thailand - Agreement with Thailand (Article II(7)), "the transfer may be refused if: (a) it is considered by the Transferring State to jeopardize its sovereignty, its security or its public order; or (b) the offender is also a national of the Transferring State."

${ }^{21}$ Agreement with Thailand (Article II(6)). 
his sentence in Canada, the minister is governed by section 10 of the ITOA which provides that he "may consider the following factors":

(a) whether, in the Minister's opinion, the offender's return to Canada will constitute a threat to the security of Canada; (b) whether, in the Minister's opinion, the offender's return to Canada will endanger public safety, including (i) the safety of any person in Canada who is a victim...of an offence committed by the offender, (ii) the safety of any member of the offender's family, in the case of an offender who has been convicted of an offence against a family member, or (iii) the safety of any child, in the case of an offender who has been convicted of a sexual offence involving a child; (c) whether, in the Minister's opinion, the offender is likely to continue to engage in criminal activity after the transfer; (d) whether, in the Minister's opinion, the offender left or remained outside Canada with the intention of abandoning Canada as their place of permanent residence; (e) whether, in the Minister's opinion, the foreign entity or its prison system presents a serious threat to the offender's security or human rights; ( $f$ ) whether the offender has social or family ties in Canada; $(\mathrm{g})$ the offender's health; ( $h$ ) whether the offender has refused to participate in a rehabilitation or reintegration program; (i) whether the offender has accepted responsibility for the offence for which they have been convicted, including by acknowledging the harm done to victims and to the community; ( $j$ ) the manner in which the offender will be supervised, after the transfer, while they are serving their sentence; ( $k$ ) whether the offender has cooperated, or has undertaken to cooperate, with a law enforcement agency; or (I) any other factor that the Minister considers relevant.

Before March 2013, the ITOA obliged the Minister to consider some of the factors above in deciding whether or not to consent to the transfer of an offender to Canada. The ITOA was amended and the word 'shall' in section 10(1) was replaced by the word 'may' to give the minister wider discretion in exercising his power to consent to the transfer of an offender to serve his sentence in Canada. The number of factors that the minister is to consider was also increased. ${ }^{22}$ Our attention now turns to the Supreme Court judgement.

\section{THE FACTS OF THE CASE AND THE ISSUES THAT THE COURT HAD TO}

\section{RESOLVE}

In March 1995 Mr Davito was convicted by a Canadian court of conspiring to import and traffic cocaine and he was sentenced to eighteen years' imprisonment. ${ }^{23}$ While he was still serving his sentence in Canada, the United States requested his

\footnotetext{
${ }^{22}$ See Jamil D. Mujuzi, supra note 1: 20.

${ }^{23}$ Divito v Canada (Public Safety and Emergency Preparedness), supra note 4, para 6.
} 
extradition to stand trial for conspiracy to possess cocaine. ${ }^{24} \mathrm{He}$ was extradited from Canada to the USA in June 2005. When he appeared in a court in the US he pleaded guilty to the charge of conspiracy to possess cocaine and was sentenced to seven and a half years in prison. ${ }^{25}$ In sentencing him 'the American court took his Canadian sentence into account and gave him credit for 145 months of time served. ${ }^{26}$ In December 2006, he requested to be transferred to serve his sentence in Canada on the basis of the International Transfer of Offenders Act. ${ }^{27}$ The USA approved his applications (he requested twice) for the transfer but on both occasions the Canadian Minister refused to consent to the transfer. ${ }^{28}$ It should be recalled that under the ITOA Canada's consent is needed before any transfer can take place. The reason for decline to consent to Mr Divito's transfer to serve his sentence in Canada given by the Minister was that Mr Divito "was identified as an organized crime member and the offence involved a significant quantity of drugs." 29 This was in line with section 10(1)(a) of the ITOA. When the Minister refused to consent to his transfer, he sought judicial review of the minister's decision on two grounds: one, that the decision was unreasonable; and two, that "the existence of a discretion in $s$ [ections] $8(1), 10(1)(a)$ and $10(2)(a)$ of the ITOA to refuse to consent to the return of a Canadian in a foreign prison violated his right to enter Canada protected by s. 6(1) of the Charter." ${ }^{\prime 30}$ In dismissing Mr Divito's review application, the Federal Court held that "in light of Mr. Divito's history of criminal activity, the decision of the Minister to deny a transfer... was reasonable" and that "the impugned provisions of the ITOA did not violate s[ection] 6(1). ${ }^{31} \mathrm{His}$ appeal to the Federal Court of Appeal was also dismissed. ${ }^{32}$ It is against that background that he appealed to the Supreme Court. His argument before the Supreme Court was that "once a foreign jurisdiction consents to a transfer, he has an absolute right as a citizen to enter Canada. The Canadian government has no discretion to refuse the transfer of a Canadian citizen who is lawfully incarcerated by a foreign state. ${ }^{\prime 33}$

The issues before the Supreme Court were whether sections "10(1)(a) and $10(2)$ (a) read in conjunction with [section] 8(1), of the [ITOA] infringe the right guaranteed by [section] 6(1) of the Canadian Charter of Rights and Freedoms;" and if those sections infringe section $6(1)$ of the Charter, is the infringement "a reasonable limit prescribed by law that can be demonstrably justified in a free and

\footnotetext{
24 Ibid.

25 Ibid., para 7.

26 Ibid.

27 Ibid., para 8.

28 Ibid.

29 Ibid., para 9.

30 Ibid., para 10.

31 Ibid., para 11.

32 Ibid., para 12.

33 Ibid., para 14.
} 
democratic society under [section] 1 of the Canadian Charter of Rights and Freedoms?"34 What is evident is that the issues were raised in the context of the Canadian Charter of Rights and Freedoms. But in resolving those issues, the majority and the minority decisions referred to both the Canadian Charter of Rights and Freedoms and Canada's international human rights obligations. It is now to those findings that we turn.

\section{THE HOLDING AND THE COURT'S USE OF INTERNATIONAL LAW, PREVIOUS JUDGEMENTS AND ACADEMIC PUBLICATIONS TO RESOLVE THE ISSUES}

The majority ${ }^{35}$ referred to, inter alia, section 6(1) of the Canadian Charter of Rights and Freedoms which provides that 'Every citizen of Canada has the right to enter, remain in and leave Canada.' They made is very clear that the 'focus of the appeal' was on section 6(1) of the Canadian Charter of Rights and that that section has three rights: the right to enter, the right to remain in, and the right to leave Canada. ${ }^{36}$ They were quick to define the ambit of the appeal by stating that "only the right to enter" was at issue in the appeal. ${ }^{37}$ Referring to the Court's earlier jurisprudence, they held that section 6(1), like any other section, had to be defined generously. ${ }^{38}$ Against that background, they held that "the inquiry necessarily begins with an analysis of the purpose of the guarantee in s[ection] 6(1) and a consideration of what the right of citizens to enter Canada was intended to protect. ${ }^{139}$ After referring to academic publications on the origin of the concept of human rights protection, ${ }^{40}$ they observed that "Canada's international obligations and relevant principles of international law are also instructive in defining the right. ${ }^{\prime 41}$ In support of that position, they referred to the Supreme Court's previous decisions emphasising the role of international law in interpreting the Canadian Charter of Human Rights and Freedoms. ${ }^{42}$ They also made reference to academic publications on this issue. ${ }^{43}$ It was observed that in interpreting section 6(1) the Court was to refer to Article 12 of the International Covenant on Civil and Political Rights which had been ratified by 167 states including Canada. ${ }^{44}$ In the majority's

\footnotetext{
34 Ibid., para 13.

35 Abella, Rothstein, Cromwell, Moldaver, Karakatsanis and Wagner J] (the judgement was delivered by Abella J).

${ }^{36}$ Ibid., para 18.

37 Ibid.

38 Ibid., para 19.

39 Ibid., para 20.

40 Ibid., para 21.

41 Ibid., para 22.

42 Ibid., paras $22-23$.

43 Ibid., para 24.

${ }^{44}$ Ibid.
} 
opinion, it was necessary to refer to the ICCPR because "[a]s a treaty to which Canada is a signatory, the ICCPR is binding. As a result, the rights protected by the ICCPR provide a minimum level of protection in interpreting the mobility rights under the Charter. ${ }^{\prime 45}$ It is on that basis that the majority reproduced ${ }^{46}$ Article 12 of the International Covenant on Civil and Political Rights which provides that:

1. Everyone lawfully within the territory of a State shall, within that territory, have the right to liberty of movement and freedom to choose his residence.

2. Everyone shall be free to leave any country, including his own.

3. The above-mentioned rights shall not be subject to any restrictions except those which are provided by law, are necessary to protect national security, public order (ordre public), public health or morals or the rights and freedoms of others, and are consistent with the other rights recognized in the present Covenant.

4. No one shall be arbitrarily deprived of the right to enter his own country.

The majority emphasised Article 12(4). The majority also referred to the Human Rights Committee's General Comment No 27 on the question of the meaning of 'arbitrary' under article 12(4) of the ICCPR. In that General Comment, the Human Rights Committee stated that:

In no case may a person be arbitrarily deprived of the right to enter his or her own country. The reference to the concept of arbitrariness in this context is intended to emphasize that it applies to all State action, legislative, administrative and judicial; it guarantees that even interference provided for by law should be in accordance with the provisions, aims and objectives of the Covenant and should be, in any event, reasonable in the particular circumstances. The Committee considers that there are few, if any, circumstances in which deprivation of the right to enter one's own country could be reasonable. A State party must not, by stripping a person of nationality or by expelling an individual to a third country, arbitrarily prevent this person from returning to his or her own country. ${ }^{47}$

The majority held that the above comment by the Human Rights Committee indicates that "[t]he right to enter protected by s[ection] 6(1) of the Charter should therefore be interpreted in a way that is consistent with the broad protection under international law. ${ }^{\prime 48}$ The majority held that unlike other rights under section 6 , the rights under section 6(1) are not subject to limitations. ${ }^{49}$ The majority referred to the drafting history of the ITOA and held that it is meant to implement Canada's

\footnotetext{
${ }^{45}$ Ibid., para 25.

${ }^{46}$ Ibid.

47 Ibid., para 26 [emphasis added by the court].

${ }^{48}$ Ibid., para 27.

${ }^{49}$ Ibid., para 28.
} 
international law obligations. ${ }^{50}$ The majority observed that the 'essence' of the appellant's argument is that sections $8(1), 10(1)(a)$ and $10(2)(a)$ "operate in a way that violates [his] right to enter Canada under s[ection] 6(1) of the Charter, a right he says is automatic once the foreign jurisdiction consents to the transfer. ${ }^{151}$ The majority added that those sections:

$[P]$ rovide the Minister with a discretion whether to consent to the transfer of a Canadian offender. [The appellant] argues that there should be no discretion once an incarcerated citizen's transfer is consented to by a foreign jurisdiction, the citizen's right to enter under s[ection] 6(1) of the Charter requires that the Minister consent. In essence, [the appellant] argues that $s$ [ection] 6(1) includes an automatic right to serve a foreign prison sentence in Canada if the foreign state consents. His submission would result in a positive obligation on Canada to administer the sentences imposed upon Canadian citizens by foreign jurisdictions. This...misconstrues what s[ection] 6(1) protects. ${ }^{52}$

The majority referred to publications on the issue of state sovereignty in international law and how it relates to the question of the transfer of offenders between countries and held that "as a matter of international law, Canada has no legal authority to require the return of a citizen who is lawfully incarcerated by a foreign state. ${ }^{153}$ The majority also referred to the purpose of the transfer of offenders between Canada and the USA as stated in the treaty between the two countries and also the purpose of the transfer of offenders between countries ${ }^{54}$ and held that the consent of the sentencing state and that of the administering state is required in the transfer of offenders because "The ITOA was not intended to create a right for Canadian citizens to require Canada to administer their foreign sentence. ${ }^{\prime \prime 5}$ The majority added that:

The ability of prisoners to serve their sentence in Canada is therefore a creation of legislation. Independent of the ITOA, there is no right to serve a foreign prison sentence in Canada... [A]lthough the ITOA contemplates a mechanism by which a citizen may return to Canada in the limited context of continuing incarceration for the purpose of serving their foreign sentence, s[ection] 6(1) does not confer a right on Canadian citizens to serve their foreign sentences in Canada. ${ }^{56}$

The majority concluded that:

\footnotetext{
${ }^{50}$ Ibid., paras $31-36$.

${ }^{51}$ Ibid., para 38.

52 Ibid., para 39.

${ }^{53}$ Ibid., para 40 [emphasis in the original].

54 Ibid., paras $41-43$.

55 Ibid., para 44 [emphasis in original].

${ }^{56}$ Ibid., para 45.
} 
The mobility rights in s[ection] 6(1) should be construed generously, not literally, and, absent a literal interpretation, I am unable to see how s[ection] $6(1)$ is breached in the circumstances of this case. Canadian citizens undoubtedly have a right to enter Canada, but Canadian citizens who are lawfully incarcerated in a foreign jurisdiction cannot leave their prison, let alone leave to come to Canada. What makes the entry to Canada possible is the ITOA. But this possibility does not thereby create a constitutionally protected right to leave a foreign prison and enter Canada whenever a foreign jurisdiction consents to the transfer. Nor does it impose a duty on the Canadian government to permit all such citizens to serve their foreign sentences in Canada. The impugned provisions of the ITOA, which make a transfer possible, do not, as a result, represent a breach of s[ection] $6(1) .{ }^{57}$

The majority added that although the issue of whether or not the minister had exercised his discretion reasonably in this case was not raised in the appeal, the minister's discretion under sections 81 and 10(1)(a) and 10(2)(a), "must be exercised reasonably, including in compliance with relevant Charter values. ${ }^{\prime 58}$

Like the majority decision, the minority ${ }^{59}$ were in agreement with the majority on the role of international law and the legislative history of the ITOA in interpreting the right in question. ${ }^{60}$ They did not agree with the majority's position that the issue to be resolved was "whether the mobility rights guaranteed by s[ection] 6(1) of the Charter give Canadian citizens incarcerated abroad the right to require Canada to administer their foreign prison sentences whenever the foreign jurisdiction consents to the transfer." 61 They observed that "[a] correct interpretation of the right to enter Canada...demands an acknowledgment that effective exercise of the rights conferred by s[ection] 6(1) will often require the state's active cooperation. ${ }^{\prime \prime 2}$ They held that:

By its enactment of the ITOA and signature of the treaties the ITOA implements, Parliament and the Canadian government have recognized and encouraged the use of international prisoner transfers as a means of enabling Canadian citizens incarcerated abroad to enter and remain in Canada. The ITOA was precisely designed to safeguard and facilitate the exercise of these s. $6(1)$ rights. ${ }^{63}$

They held that "[i]t is inconsistent to find that an international prisoner transfer has constitutional significance with respect to the right to remain in

\footnotetext{
57 Ibid., para 48.

58 Ibid., para 49.

${ }^{59}$ Chief Justice McLachlin and LeBel and Fish JJ. The judgement was delivered by LeBel and Fish JJ.

${ }^{60}$ Ibid., para 55.

${ }^{61}$ Ibid., para 59.

62 Ibid., para 60.

63 Ibid., para 63.
} 
Canada, but does not engage the constitutional right to enter Canada." ${ }^{64}$ The minority held further that:

Parliament has crafted a regime whereby once the foreign state has consented to a transfer - thus removing the practical restrictions on an incarcerated citizen's ability to return to Canada - the sole impediment to the exercise of the citizen's s[ection 6(1) right is the Minister's discretion. A statutory regime that grants a Minister the discretion to determine whether or not citizens can exercise their Charter-protected right to enter Canada constitutes, prima facie, a limit on the s[ection] 6(1) right of the citizens in question. ${ }^{65}$

They concluded that sections " $8(1), 10(1)(a)$ and $10(2)(a)$ of the ITOA constitute a limitation on the rights protected by $\mathrm{s}$ [ection] 6(1) of the Charter. ${ }^{\prime \prime 6}$ They held that the above sections were not unconstitutional because:

Manifestly, the factors set out in [sections] 10(1)(a) and 10(2)(a) relate to risks that arise upon the transfer of offenders, before their release. Denying a prisoner transfer request based on security risks that may arise only after an offender's release would be an unreasonable exercise of discretion grounded in an erroneous interpretation of the ITOA. A Minister's exercise of discretion in such an unreasonable manner, however, does not render the factors themselves irrational. Properly understood, the factors and the Minister's discretion are rationally connected to Parliament's pressing and substantial objectives. ${ }^{67}$

They added that:

Given that in some cases the objectives of the ITOA would be served by refusing a transfer based on the factors set out in ss. 10(1)(a) and 10(2)(a), the Minister's discretion to consider these factors on a case-by-case basis is rationally connected to the pressing and substantial objectives of these provisions. In addition, at least in some cases, refusing a transfer based on the challenged factors will be the sole - and therefore the most minimally impairing - alternative open to the Minister. In light of both the binary nature of the Minister's decision and the citizen's continued incarceration, it is difficult to conceive of a less drastic means of achieving Parliament's protective purpose. Finally, in our view, the impugned provisions are proportionate in their effect that is their effects do "not so severely trench on individual or group rights that the legislative objective, albeit important, is nevertheless outweighed by the abridgement of rights". ${ }^{68}$

They held further that "t]he prejudicial effect of a transfer refusal on the mobility rights of Canadian citizens incarcerated abroad is further palliated by the

\footnotetext{
${ }^{64}$ Ibid., para 58.

${ }^{65}$ Ibid., para 64.

${ }^{66}$ Ibid., para 67.

${ }^{67}$ Ibid., para 76.

${ }^{68}$ Ibid., paras 78 - 80 [emphasis removed].
} 
fact that the citizens in question will be able to enter Canada after serving their sentences in the foreign jurisdiction. ${ }^{\prime \prime 9}$ They concluded that:

The Minister's discretion to grant or refuse prisoner transfer requests under the ITOA is broad and flexible. A large measure of deference is appropriate in the circumstances, given the complex social and political problems being tackled, such as security and terrorism... Each individual decision by the Minister must nonetheless respect the governing principles of administrative law and, of course, remains subject to judicial review. Moreover, the Minister's discretion must be exercised with due regard for the s[section] 6(1) Charter rights at stake. $^{70}$

\section{ANALYSING THE JUDGEMENT AND HIGHLIGHTING ITS HUMAN RIGHTS IMPLICATIONS}

The following section will analyse the judgement and highlight its implications. The author will also demonstrate that the judgement, read in light of Canada's national and international human rights obligations, creates an opportunity for the issue of human rights to be brought to the fore in making the decision of whether or not the offender should be transferred to serve his sentence in Canada once the sentencing state has consented to the transfer.

The first point relates to the interpretative approaches that the court invoked to deal with the issues that were raised. As indicated earlier, the court referred to the ICCPR and to the Human Rights' Committee General Comment 27 in interpreting the meaning of the right to enter Canada as provided for under section $6(1)$ of the Charter. In justifying why it had invoked the ICCPR, the court held that that treaty was binding on Canada because Canada has ratified it. This should be understood against the background that unlike the constitutions of some countries such as South Africa, ${ }^{71}$ and Malawi ${ }^{72}$ which expressly empower courts to refer to international law in interpreting the bill of rights, the Canadian Charter does not expressly allow courts to refer to international law in interpreting the Charter. The implication for the ruling is that the court has continued with its practice of referring to international law, especially the treaties which have been ratified by Canada, in interpreting the rights in the Charter. ${ }^{73}$ The Court also readily accepted the Human

\footnotetext{
69 Ibid., para 83.

70 Ibid., paras 85 - 86 [emphasis removed].

71 Section 39(1)(b) of the Constitution (1996).

72 Section 11(2)(c) of the Constitution (1994).

73 For the role of international law in interpreting the Charter see: Daniela Bassan, "The Canadian Charter and Public International Law: Redefining The State's Power to Deport Aliens," Osgoode Hall Law Journal 34:3 (1996); John Claydon, "Use of International Human Rights Law to Interpret Canada's Charter of Rights and Freedoms," Connecticut Journal of International Law 2 (1986-1987); M. Ann Hayward, "International Law and the Interpretation of the Canadian Charter of Rights and Freedoms: Uses and Justifications," University of Western Ontario Law Review 23 (1985).
} 
Rights Committee's interpretation of the ICCPR as a guide to understanding the rights under the Charter and in particular the right to enter Canada. In other words, the court indirectly suggests that in understanding Canada's obligations under international law, the inquiry should go beyond the text of the treaty in question and should be extended to the jurisprudence and practice of the relevant international human rights body - in this case the Human Rights Committee.

The second point flows directly from the first. In the author's opinion it is surprising that the majority, after referring to article 12 of the ICCPR and General Comment 27, did not find that the relevant sections of the ITOA infringed on the right to enter one's own country. Article 12(4) of the ICCPR clearly recognises that right and the General Comment in question states the circumstances in which such a right may be infringed upon. In the author's opinion, the correct approach would have been, as the minority stated, to find that sections $8(1)$ and 10(1)(a) and $10(2)(a)$ of the ITOA violated the right to enter under section $6(1)$ of the Charter and under Article 12(4) of the ICCPR and then proceed to investigate whether the violation in question was justified in the light of the other relevant provisions of the Charter, the drafting history of Article 12(4) of the ICCPR, ${ }^{74}$ the text of the treaty itself and the jurisprudence and practice of the Human Rights Committee. I will illustrate how that approach would have enriched the court's reasoning. The discussion below will exclude the limitations on the rights under the Charter as those limitations were dealt with by the minority judgement in arriving at the conclusion it did.

The drafting history of Article 12(4) of the ICCPR shows that "the general consensus was... that,...the right [to enter one's country] was not absolute. ${ }^{\prime 75}$ In fact, Canada submitted, although that amendment was later withdrawn, that Article 12(4) should provide that "[u]nless lawfully exiled, anyone shall be free to enter the country of which he is a citizen." ${ }^{\prime 76}$ The drafting history of Article 12(4) also shows that "[i]t was thought inconceivable, for example, that a State should prohibit one of its nationals from entering its territory for reasons of health or morality." 77 Although by the time the Article 12(4), and indeed the whole of the ICCPR was being debated, the issue of the transfer of offenders from one country to another was on the international agenda, ${ }^{78}$ the author is not aware of any country which proposed that one of the grounds that could or could not be invoked to limit

\footnotetext{
74 I should hasten to add that even the minority judgement does not refer to the drafting history of Article 12(4) of the ICCPR.

75 Marc J Bossuyt, Guide to the "Travaux Préparatoires" of the International Covenant on Civil and Political Rights (Dordrecht: Martinus Nijhoff Publishers, 1987), p. 262.

76 Ibid., p. 260.

77 Ibid., p. 262.

78 Michael Plachta, Transfer of Prisoners under International Instruments and Domestic Legis/ation: A Comparative Study (Freiburg: Max Planck Institute for Foreign and International Criminal Law, 1993), pp. 134-227.
} 
a person's right to enter one's country was that he was serving a prison sentence abroad. What is critical is that a person should not be arbitrarily deprived of the right to enter his own country. ${ }^{79}$ It has been argued that "[i]n light of the historical background, there can be no doubt that the limitation on the right to entry expressed with the word 'arbitrarily' ... is to relate exclusively to lawful exile as punishment for a crime, whether this is accompanied by loss of nationality or not. ${ }^{\prime 80}$ The jurisprudence emanating from the Human Rights Committee has indeed dealt with the right to enter one's own country. For example, the Human Rights Committee called upon Croatia to "ensure that no difficulties are put in the way of persons who left Croatia as a result of the armed conflict, in exercising their right, under article 12, paragraph 4, of the Covenant to return to their own country. ${ }^{81}$ The Human Rights Committee also recommended to Kuwait that "[t]he right to remain in one's country and to return to it must be scrupulously respected. ${ }^{182}$

The Human Rights Committee has also handed down a number of communications on the issue of a person's right to enter his country some of which have been brought against Canada. ${ }^{83}$ However, the author is not aware of any communications in which the Human Rights Committee has dealt with the issue of the person's right to enter his country in the context of serving a prison sentence. It is worth noting that in Albert Womah Mukong $v$. Cameroon ${ }^{84}$ in finding that the applicant's right under article 12(4) had not been violated by the state party, the Human Rights Committee observed that:

$[T]$ he Committee notes that the author was not forced into exile by the State party's authorities...but left the country voluntarily, and that no laws or regulations or State practice prevented him from returning to Cameroon. As the author himself concedes, he was able to return to his country in April 1992; even if it may be that his return was made possible, or facilitated, by diplomatic intervention, this does not change the Committee's conclusion that there has been no violation of article 12 , paragraph 4 , in the case. ${ }^{85}$

\footnotetext{
${ }^{79}$ Marc J Bossuyt, supra note 75, p. 262.

80 Manfred Nowak, U.N. Covenant on Civil and Political Rights: CCPR Commentary (Kehl: N.P. Engel, 1993), p. 219 [emphasis in the original].

81 Concluding Observations of the Human Rights Committee on Croatia's Initial Report, CCPR/CO/71/HRV (April 30, 2001), para 15.

82 UN Human Rights Committee, Concluding Observations: Kuwait, CCPR/CO/69/KWT (July 27, 2000), para 15. The Human Rights Committee made this recommendation in the context of people who had left Kuwait during the Iraqi occupation in $1990-1991$.

${ }^{83}$ A.S., on her own behalf and on behalf of her daughter and grandson v. Canada, 068/1980 (the communication held inadmissible); Charles E. Stewart v. Canada, 538/1993 (dealt with deportation from Canada of a non-national); Giosue Canepa v. Canada, 558/1993 (deportation from Canada of a nonnational); Ruediger Schlosser v. Czech Republic, 670/1995 (communication held inadmissible); Simalae Toala et al. v. New Zealand, 675/1995 (deportation of a non-national); Ati Antoine Randolph v. Togo, 910/2000; Francesco and Anna Madafferi and their children v. Australia, 1011/2001 (deportation of a non-national); and Jama Warsame $v$. Canada, 1959/2010 (deportation of a non-national).

${ }^{84}$ Albert Womah Mukong v. Cameroon, 458/1991.

${ }^{85}$ Ibid., para 9.10.
} 
In Luis Asdrúbal Jiménez Vaca v. Colombia ${ }^{86}$ the Human Rights Committee held that:

[C]onsidering the Committee's view that the right to security of person (art. 9, para. 1) was violated and that there were no effective domestic remedies allowing the author to return from involuntary exile in safety, the Committee concludes that the State party has not ensured to the author his right to remain in, return to and reside in his own country. Paragraphs 1 and 4 of article 12 of the Covenant were therefore violated. ${ }^{87}$

The above communications and practice show, inter alia, that there are different ways through which a person's right to enter his country could be violated. These include the existence of laws, regulations or state practices which make it impossible for him to return to his country or the fact that security situation is of such a nature that his return to the country would be risky. In light of the above drafting history of the ICCPR and the practice and jurisprudence from the Human Rights Committee, the author wishes to emphasize here that the minority were right in concluding that relevant sections of the ITOA indeed infringed on the offender's right to enter Canada but that that infringement did not render the relevant provisions unconstitutional or contrary to Canada's international human rights obligations as the right to enter one's country is not absolute.

Related to the above is the issue of whether an offender has a right to be transferred to serve his sentence in Canada once the sentencing state has consented to the transfer. The Court, both the minority and the majority, agreed that an offender does not have the right. Courts in Canada had, before the Supreme Court decision, in several decisions held that an offender does not have a right to be transferred and serve his sentence in Canada. ${ }^{88}$ This position is not unique to Canada. Courts in other countries such as the USA ${ }^{89}$ have also interpreted the relevant piece of legislation to conclude that an offender does not have the right to be transferred and serve his sentence in his country of nationality or citizenship. The European Court of Human Rights is also of the view that an offender does not have the right to be transferred and serve a sentence in his county of nationality or citizenship. ${ }^{90}$ The implication for the Supreme Court ruling lies in the fact the issue is now settled that a Canadian serving a prison sentence abroad cannot invoke section 6(1) of the Charter to argue that he has the right to be transferred and serve his sentence in Canada. Because of the fact that the Supreme Court's decision dealt with human rights issues, the questions that arises is whether the

\footnotetext{
${ }^{86}$ Luis Asdrúbal Jiménez Vaca v. Colombia, 859/1999.

87 Ibid., para 7.4 .

88 Jamil D. Mujuzi, supra note 1: $12-13$.

${ }^{89}$ Ibid.: $16-17$.

90 Plepi v Albania and Greece, 51 EHRR 3, 53 (2010).
} 
Supreme Court's judgement leaves room for the argument that there could be cases where the Minister will be obliged, on human rights grounds, to consent to the offender's transfer to Canada once the sentencing state has consented to the transfer. This is the issue to which our attention now shifts.

It has been illustrated above that the minister has various factors to consider in determining whether or not to allow the offender to be transferred and serve his sentence in Canada. As mentioned above, the court held that in exercising his discretion the minister must act reasonably. ${ }^{91}$ The implication is that if he declines to consent to the offender's transfer on unreasonable grounds, courts will be in a position to set aside the minister's decision. Evidence shows that in the past Canadian courts have set aside the minister's decisions not to consent to the transfer of offenders where they have found the decisions to have been based on unreasonable grounds. ${ }^{92}$ In one case the minister was ordered to consent to the offender's transfer within a few weeks. ${ }^{93}$ It would appear that the Supreme Court decision raises new issues that could be invoked to compel the minister to consent to the transfer of an offender to Canada - in other words, the presence of these issues could be invoked to successfully argue that the minister's decision not to consent to the offender's transfer was unreasonable.

In coming to the conclusion that a Canadian national who has been convicted of an offence in a foreign country does not have the right to be transferred to serve his sentence in Canada, the court held that such an offender is "lawfully incarcerated" in that country after having been "lawfully convicted in a foreign jurisdiction." ${ }^{\prime \prime 4}$ In the author's view this holding raises the question of whether an offender who has been imprisoned in a foreign country after having been unlawfully convicted could invoke that as an argument to motivate for his transfer to Canada. This scenario could arise in a case where the person in question was convicted after a trial which did not meet international human rights standards - that is, where there was a flagrant denial of justice; or, for example, where the evidence which was relied on by the court for his conviction was obtained through torture. ${ }^{95}$ Related to the above is the issue of the offender's continued imprisonment in Canada when the Canadian authorities are of the view that his conviction and subsequent detention in a foreign country were unlawful. To the best of the author's knowledge, Canadian courts have not dealt with that issue. However, the European

\footnotetext{
91 Divito v Canada (Public Safety and Emergency Preparedness), supra note 4, para 49.

92 Jamil D. Mujuzi, supra note 1: 12-13.

93 Ibid.: 13-15.

94 Divito v Canada (Public Safety and Emergency Preparedness), supra note 4, para 47.

${ }^{95}$ Article 15 of the Convention against Torture provides that "Each State Party shall ensure that any statement which is established to have been made as a result of torture shall not be invoked as evidence in any proceedings, except against a person accused of torture as evidence that the statement was made."
} 
Court of Human Rights and courts in the UK have held that it would be contrary to the European Convention on Human Rights to continue with the imprisonment of a person whose sentence in a foreign state was as a result of a trial that amounted to a flagrant denial of justice. ${ }^{96}$ Canadian courts could also follow that approach.

Another issue relates to that of human rights generally. It should be recalled that section $10(1)(e)$ of the ITOA provides that one of the factors that the minister may consider in deciding whether or not to consent to the transfer of an offender to Canada is 'whether, in the Minister's opinion, the foreign entity or its prison system presents a serious threat to the offender's security or human rights.' It is argued that if there is evidence that the offender's internationally recognised absolute rights such as the right to freedom from torture are being violated, the minister has an obligation to consent to the offender's transfer to Canada. This is because of the fact that by not consenting to the transfer of such an offender, the minister would be indirectly giving the state in question an opportunity to continue to subject a Canadian citizen to torture. But the minister could also be compelled to consent to the offender's transfer if the offender's right to healthcare is being violated. This is because section $10(1)(\mathrm{g})$ empowers the minister to consider 'the offender's health' as one of the factors in deciding whether or not to consent to the offender's transfer to Canada. Whether or not the right in question is an absolute right is not the yardstick by which to assess whether the minister exercised his discretion reasonably. The ultimate test is whether, to use the Court's words, the minister "exercised [his discretion] reasonably, including in compliance with relevant Charter values." 97

Another issue relates to the question of rehabilitation. Section 10(1) (h) provides that one of the reasons that the minister may consider in deciding whether to consent to transfer of the offender to serve his sentence in Canada is 'whether the offender has refused to participate in a rehabilitation or reintegration program.' The Supreme Court emphasised the fact that the purpose of the treaties on the transfer of offenders between Canada and other countries is to promote the rehabilitation and social reintegration of offenders. ${ }^{98}$ This fact has also been emphasised by Canadian courts in different judgements. ${ }^{99}$ Article 10(3) of the ICCPR also provides that "[t]he penitentiary system shall comprise treatment of prisoners the essential aim of which shall be their reformation and social

\footnotetext{
96 See Jamil D Mujuzi, "Analysing the Agreements (Treaties) on the Transfer of Sentenced Persons (Offenders/Prisoners) between the United Kingdom and Asian, African and Latin American Countries," European Journal of Crime, Criminal Law and Criminal Justice 20 (2012): 388 - 390.

97 Divito v Canada (Public Safety and Emergency Preparedness), supra note 4, para 49.

98 Ibid., para 42.

99 Jamil D. Mujuzi, supra note 1: 5-9.
} 
rehabilitation." ${ }^{100}$ The court also held that the minister can invoke the ITOA to prevent the offender from entering Canada before he has completed serving his sentence not after he has finished serving his sentence. ${ }^{101}$ It is the author's view that if an offender refuses to participate in rehabilitation programmes in a foreign prison on the basis that such programmes are irrelevant to him or if there are no rehabilitation programmes in the prison in question, the offender could argue that his transfer should be approved so that he is rehabilitated in Canada. Although the Court held that in some cases the objectives of the ITOA would also "be served by refusing a transfer based on the factors set out in [sections] 10(1)(a) and $10(2)(a)^{\prime 102}$ it is difficult to think of a situation where the object of the Act would be achieved by refusing to consent to the offender's transfer on the basis that he has refused to take part in rehabilitation programmes he considers to be useless or where he is being imprisoned in prison where there are no rehabilitation programmes at all.

\section{CONCLUSION}

In this article I have discussed the Supreme Court of Canada's judgement which dealt with the issue of whether sections 8(1) and 10(1)(a) and section $10(2)(a)$ of the ITOA were contrary to section $6(1)$ of the Charter. I have illustrated how the majority and the minority relied on international law, previous court decisions and academic publications to resolve the issues that they were dealing with. I have also agreed with the minority that the majority erred by adopting the approach they adopted. In my view, both the majority and the minority could have enriched their decisions if they had referred to the drafting history of Article 12(4) of the ICCPR and to more jurisprudence and practice from the Human Rights Committee. Although the decision dealt with two sections of the ITOA, the judgment is applicable to all the relevant factors in the ITOA that the minister may consider in deciding whether or not to consent to the offender's application to be transferred and serve his sentence in Canada. The appropriate test to be applied in all cases in which the offender is challenging the minister's decision not to consent to his transfer to Canada is whether the minister "exercised [his discretion] reasonably, including in compliance with relevant Charter values." ${ }^{103}$ In other

\footnotetext{
${ }^{100}$ In its recommendation to the Government of Italy, the Working Group on Arbitrary Detention stated that "[t]he Government should also consider ways to ensure that reformation and social rehabilitation of the offender, which are essential aims of imprisonment according to ... article 10 ICCPR ... are not sacrificed to public security concerns" (see Report of the Working Group on Arbitrary Detention, Mission to Italy, A/HRC/10/21/Add.5 (January 26, 2009), para 114.

${ }^{101}$ Divito $v$ Canada (Public Safety and Emergency Preparedness), supra note 4, para 76.

102 Ibid., para 78.

103 Ibid., para 49.
} 
words, human rights issues are likely to feature prominently in proceedings of this nature.

\section{BIBLIOGRAPHY}

1. Bassan, Daniela. "The Canadian Charter and Public International Law: Redefining the State's Power to Deport Aliens." Osgoode Hall Law Journal 34:3 (1996): 584-625.

2. Bossuyt, Marc J. Guide to the "Travaux Préparatoires" of the International Covenant on Civil and Political Rights. Dordrecht: Martinus Nijhoff Publishers, 1987.

3. Claydon, John. "Use of International Human Rights Law to Interpret Canada's Charter of Rights and Freedoms." Connecticut Journal of International Law 2 (1986-1987): 349-360.

4. Concluding Observations of the Human Rights Committee on Croatia's Initial Report. CCPR/CO/71/HRV (April 30, 2001).

5. Hayward, M. Ann. "International Law and the Interpretation of the Canadian Charter of Rights and Freedoms: Uses and Justifications." University of Western Ontario Law Review 23 (1985): 9-20.

6. Mujuzi, Jamil D. "Analysing the Agreements (Treaties) on the Transfer of Sentenced Persons (Offenders/Prisoners) between the United Kingdom and Asian, African and Latin American Countries." European Journal of Crime, Criminal Law and Criminal Justice 20 (2012): 377 - 414.

7. Mujuzi, Jamil D. "The Transfer of Offenders from Other Countries to Canada: Analysing the Theory and Practice." The Chinese Journal of Comparative Law (2013): 1-35 // doi:10.1093/cjcl/cxt019.

8. Nowak, Manfred. U.N. Covenant on Civil and Political Rights: CCPR Commentary. Kehl: N.P. Engel, 1993.

9. Plachta, Michael. "Human Rights Aspects of the Prisoner Transfer in a Comparative Perspective." Louisiana Law Review 53 (1993): 1043-1089.

10. Plachta, Michael. Transfer of Prisoners under International Instruments and Domestic Legislation: A Comparative Study. Freiburg: Max Planck Institute for Foreign and International Criminal Law, 1993.

11. Report of the Working Group on Arbitrary Detention, Mission to Italy. A/HRC/10/21/Add.5 (January 26, 2009).

12. United Nations Human Rights Committee. Concluding Observations: Kuwait. CCPR/CO/69/KWT (July 27, 2000). 
13. United Nations Office on Drugs and Crime. Handbook on the International Transfer of Sentenced Persons. New York, 2012.

\section{LEGAL REFERENCES}

1. A.S., on her own behalf and on behalf of her daughter and grandson $v$. Canada. Human Rights Committee Case. 068/1980.

2. Agreement between Canada and France on the Transfer of Inmates and the Supervision of Persons under Sentence. E102458-CTS 1984, No. 32.

3. Agreement between the Government of Canada and the Government of Barbados on the Transfer of Offenders. E104967, Canada Treaty Series, 2003/8.

4. Agreement between the Government of Canada and the Government of the Arab Republic of Egypt on the Transfer of Sentenced Persons. E102464-CTS 2000, No. 9.

5. Agreement of Co-Operation Regarding the Transfer of Persons Incarcerated Under Sentence between the Government of Canada and the Government of the Kingdom of Morocco. E102460-CTS 1996, No. 32.

6. Albert Womah Mukong v. Cameroon. Human Rights Committee Case. 458/1991.

7. Ati Antoine Randolph v. Togo. Human Rights Committee Case. 910/2000.

8. Catenacci v. Canada (Attorney General). 2006 CarswellNat 1364, 2006 FC 539, 144 C.R.R. (2d) 128, 291 F.T.R. 215.

9. Charles E. Stewart v. Canada. Human Rights Committee Case. 538/1993.

10. Divito v. Canada (Public Safety and Emergency Preparedness). 2013 SCC 47 (September 19, 2013).

11. Francesco and Anna Madafferi and their children v. Australia. Human Rights Committee Case. 1011/2001.

12. Giosue Canepa v. Canada. Human Rights Committee Case. 558/1993.

13. Jama Warsame v. Canada. Human Rights Committee Case. 1959/2010.

14. Luis Asdrúbal Jiménez Vaca v. Colombia. Human Rights Committee Case. 859/1999.

15. Plepi v. Albania and Greece. 51 EHRR 3, 53 (2010).

16. Ruediger Schlosser v. Czech Republic. Human Rights Committee Case. 670/1995.

17. Simalae Toala et al. v. New Zealand. Human Rights Committee Case. 675/1995. 
18. Treaty between Canada and Bolivia on the Transfer of Inmates and the Supervision of Persons under Sentence. E102457-CTS 1985, No. 4.

19. Treaty between Canada and the United Mexican States on the Execution of Penal Sentences. E102459-CTS 1979, No. 3.

20. Treaty between Canada and the United States of America on the Execution of Penal Sentences. E102461-CTS 1978, No. 12.

21. Treaty between the Government of Canada and the Government of Mongolia on the Transfer of Offenders. E105008, Canada Treaty Series 2005/2.

22. Treaty between the Government of Canada and the Government of the Argentine Republic on the Transfer of Offenders. E104972, Canada Treaty Series, 2008/14.

23. Treaty between the Government of Canada and the Government of the Republic of Cuba on the Serving of Penal Sentences. E103276-CTS 1999, No. 24.

24. Treaty between the Government of Canada and the Government of the Dominican Republic on the Transfer of Offenders. E105031, Canada Treaty Series 2007/4.

25. Treaty between the Government of Canada and the Government of the Republic of Peru on the Execution of Penal Sentences. E102465-CTS 1980, No. 15.

26. Treaty on Cooperation in the Execution of Penal Sentences between the Government of Canada and the Government of the Kingdom of Thailand. E103412-CTS 1988, No. 24.

27. Treaty on Transfer of Offenders between Canada and the Federative Republic of Brazil. E102462-CTS 1998, No. 8. 